\title{
FROM DEFICIENCY TO AFFLUENCE: DYNAMICS OF KANDYAN PEASANTRIES AND THE RISE OF RURAL CASTE ELITE IN SRI LANKA
}

\author{
K.A Samitha Udayanga ${ }^{1}$
}

\begin{abstract}
During the past few decades, enormous changes in Kandyan peasantries have caused its restructuration, though some significant older structures still remain intact swaying people's behaviour. For example, attitudes toward the caste have been changed tremendously, but again it plays a significant role in contemporary rural Sri Lanka. Therefore, this paper focuses on how people in Kandyan peasantries have been involved in the market-oriented development process, and in particular, why the lowcaste people in Kandyan highland peasantries benefitted from education, once they have secured their economic gains while the high caste people have not. The research conducted using ethnomethodology reveals that the rural sector in Sri Lanka has undergone a convincing transition, while some traditional institutions were preserved. Within this transition, as the authoritative identity of the high caste people disturbed their education, in turn, prevented their upward mobility that of the low caste communities. Moreover, the market economy stimulated the upward mobility of low caste people in the contemporary Kandyan peasantries. As the market economy prevails in the country, some specific tasks performed by the low castes became market-oriented that and hastened the rise of rural elite from the low castes in Kandyan peasantries. The life of low caste elite then became stable and inspired them to drive toward a prestigious social status, during which education provided necessary means.
\end{abstract}

Keywords: Caste System, Education, Elitism, Entrepreneurship, Kandyan Peasantries, Rationality
${ }^{1}$ Department of Sociology, University of Ruhuna-Sri Lanka senithsrisami@gmail.com

https://orcid.org/00000002-9826-691X 


\section{INTRODUCTION}

Even though it is believed that the modern society is being administered by so-called rational values and principles (Weber, 1947), still some significant factors, out of rational-realm, are highly influential (Paramsothy, 2018). Caste is one among them. Many anthropologists understand the caste system as a traditional stratification system that cannot be defined in line with modernity since rationality is not applicable to the caste system (Douwe van der Ploeg, 2010) since 'Rationality' defined by modern philosophers clearly distinguish it from what laypersons perceive as rational. [Note: Rationality and Irrationality are major sociological concepts theorized by Max Weber(Weber, 1947). Rationality of the society is not just a spontaneous result, but an outcome of a historical development of a particular society with specific affiliations with science and technology. In fact, rational institutions are clearly distinguished from irrational societal structures such as caste, race and the kind.] On the contrary, "class" is identified as a modern stratification system, since it can be understood through rational principles delineated by some social anthropologists (Ember \& Ember, 2015). Rationality is one of the main characteristics, which distinguishes modern societies from traditional societies. However, both rational and irrational factors are equally important in understanding human action, since human interactions do not depend solely on deliberate rational or irrational thinking (Moran, 2000). Beliefs on which laypersons relied in a society are always rational to them, but nevertheless, those beliefs can perhaps be reinterpreted as irrational by an outsider provided that nonconventional and contextual-insensitive methods were employed though they can be more scientific (Husserl, 1965; Rescher, 2003). Living experiences of people are, therefore, more important since people often comprehend those experiences are more rational to them (Schutz, 1977).
"Rationality" is an epistemologically positioned argument by which modernity is justified and has been adopted in understanding people's everyday lives in the modern day (Shah, 2012). Though it is rather possible to argue that the concept of rationality is a quality which emanates intrinsically from the society as it evolves acquiring material growth and ideological sophistication, discrete extraction of irrationality is practically impossible since human action is difficult to determine by way of rationality or irrationality, and hence the human action would be a product of socially justified rationality, that is comprehended as rational solely by lay persons (Chung, 2013; Tepicht, 1975). However, 'rationality' defined in modernism is clearly distinguished from lay perceptions, though it seems to have interconnections between rationality and irrationality. Education, a more rational institution, for example, might intersects with the caste resulting unexpected consequences even in modern and complex urban societies.

Moreover, as the nation-state is engaged in a rational policy-making process, to ensure that the development of the country is achieved has become the ultimate objective of its political agenda. Since decolonization of the country, national leaders have strived to develop the country in many dimensions. In this process, a systematic human intervention with a justification through rational principles was required, and hence economic measures came forward at the outset of the development discourse as it comprises of rational principles such as causation (Desai \& Potter, 2011). Although the development process goes about in line with rational principles, the challenging issue is to involve people since they comply with lay-specific rationalities over imposed modern rationalities (Shiva, 1991). 
So-called rational interventions, therefore, might be reinterpreted in accordance with perceived rationality by laypersons, that would result in unexpected consequences.

Furthermore, as the globalization, a rational and inevitable process prevails, every corner of the world might experience significant changes alongside challenges (Eckes \& Zeiler, 2003; Giddens, 2003; Held, 2004; Held, McGrew, Glodblatt, \& Perraton, 1999; Stiglitz, 2002). Globalization reshapes the world. Global capital accumulation alongside technological networking provides necessary means for the globalization, which is also interpreted as a more rational process (Giddens, 2003). Globalization brought several unprecedented changes in the third world and had challenged many irrational structures (such as caste) and harnessed the mobility of people (Beteille, 2015; Leach, 1960; Roberts, 1995). Sometimes, as existing structure changes, unprecedented troubles too emerged particularly in peasantries in Sri Lanka (Robinson, 2007; Spencer, 1990; Uphoff, 1992). Furthermore, upward mobilization of peasantries has been largely supported by prevailing global values emanating from the systematically established education system, which in turn reinforced inculcating the mode of modern thoughts in the rural people. Peasantries in Sri Lanka too were influenced by the re-systematized global education during the past two decades, due to interventions by global institutions such as UNICEF and UNDP (UNDP, 2017).

As Robinson (2007) posits rational political and administrative interventions after the 1950's in Sri Lanka, highly impacted on the rural society. Traditional political structures, particularly administrative institutions of many rural societies were changed, but consequences were unexpectedly severe (Robinson, 2007).
The administrative interventions in rural Sri Lanka did not emphasize any ascribed statuses theoretically, though in the practice it is associated with conventional social structures (Robinson, 2007). The regulations instructed administrators to select suitable peasants to some rural administrative positions were purely made on the qualification basis, but the administrative positions (such as agricultural instructors in rural Sri Lanka) were allocated to the high caste people since the social structure did not support otherwise. This disturbed many aspects of the social organization including economy, religion and politics of rural Sri Lanka. Furthermore, as confusions of this transition highly affected conventional social structures, peasants adopted new value systems in their every day lives to go along with the changing society (Spencer, 1990). Rationality, therefore, shall be interpreted not in accordance with modernity but based on people's perception in relation to their everyday experiences. [note: As Raghavan (1957) specifies that rodiyas (Rodi or Gadi is the lowest caste in the Sinhalese caste hierarchy) perceive themselves as a special and important group in the society while other high caste people consider themselves inferior. This asserts that perceptions of being a member of a particular caste or a group are significant in understanding people's behaviour.]

This makes it clear that rational interventions such as development cannot separate from practices of the people, which are more rational to them though they might not be rational in the modern sphere. Many studies show that rational institutions might intersect with irrational institutions, as they are interconnected within the social structure. Education like rational institutions, therefore, might support upward mobility of the low caste people without considering conventional and ascribed identities, consequently, caste structure would reappear even in the 


\section{Original Article}

ISSN: 2279-3933

modern society with new faces (Paramsothy, 2018). This paper will, therefore, investigate how education has contributed in the achievement of economic prosperity, which in turn challenged and questioned the existing social structure in many Kandyan peasantries.

Map 1: Ceylon Map showing Kandyan highlands, the 1900s

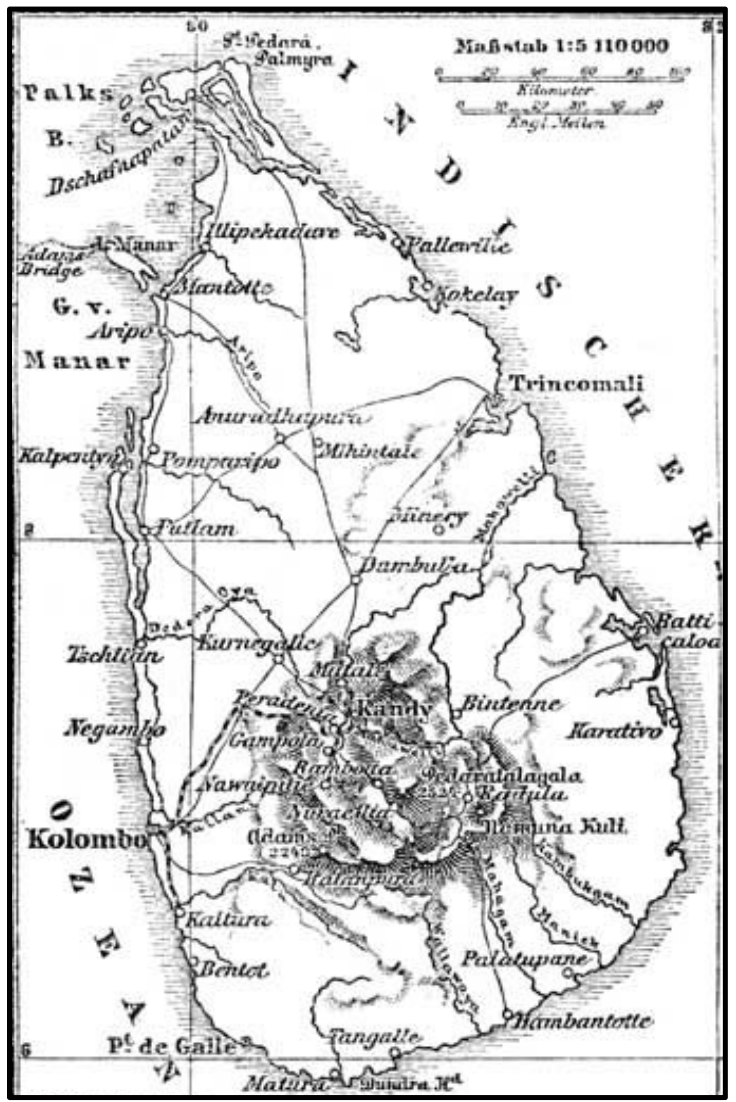

Source: 4th edition of Meyers Konversationslexikon (1885-90)

\section{LITERATURE REVIEW}

\section{Caste and Rural Development}

Since the British government imposed the capitalism on the society in spite of having a feudalistic identity in the country, it failed to initiate its own industrialization (Jayawardena, 2000). The industrialization made most of the countries opulent, but nevertheless resulted in unexpected social pathologies (Bandarage, 2007). Development with industrialization inflates the economic growth, implying the social development at last (Frederick, 1991). This was more successful in European countries, as it emerged within the European context, but less success in non-European countries since the contextual mismatch (Frank, 1993). However, developing countries had no choice except complying with the colonial administration in order to seek the nation's development. Therefore, colonization can be considered as the predecessor of all phenomenal causes of social change including globalization, urbanization, modernization and liberalization (McLeod, 2010; Patel, 2017).

As conventional values hold out while modern values prevail widely over the country due to different global forces, the rural society in Sri Lanka has undergone 
many changes confronting several challenges in terms of development and stability (Silva, 1999; Spencer, 1990). More than any other reason, globalization has steadily affected the rural society reshaping its existing social structure (Cruickshank, Lysgård, \& Magnussen, 2009; Henegedara, 2012). The process of 'Rural Development' has been one of the interventions supported by global agendas. The concept of development is identified as rational, though the implementation goes ahead on irrational societal structures, especially in rural areas (Manogaran, 1974). Therefore, those so-called rational interventions through which rural development programmes brought in, have struggled with inescapable socially constructed obstacles emanated from the rural social structure. For example, IRDP (Integrated Rural Development Programme in Sri Lanka) was more often bore upon by caste like conventional social structures.

Rural development as a successful development approach had been introduced to Sri Lanka even before the 1980's in which community development principles were introduced (Chambers, 1983, 1997). Later, community development alongside some other government-driven community development projects strived to involve peasants in the Kandyan highlands, in particular, consequently, social structure was reorganized (Uphoff, 1992). So that irrespective of the modern intervention, ascribed social structures like the caste system were associated with many development projects on the whole (Scudder, 1997, 2005; Uphoff, 1992). However, the ways in which different caste groups interacted with these development interventions were quite different.

The feudalistic ideology was not transformed into a considerable extent with structural transformation of the country even after the British colonization and postcolonization (Jayawardena, 2000; Roberts, 1995) so that, every aspect of peasantries influenced by that ideology, which is particularly twisted around the caste system. The Kandyan rural societies still search for those caste functionalities, and which is likely to have some importance in the social order of peasantries. Furthermore, the caste system comprises of a strong socio-economic dimension and particularly entwined with the rational social institutions such as education, health and the kind. Seemingly, education is also associated with caste like irrational institutions in rural Sri Lanka.

\section{Prosperity, Community and Rational Institutions}

This research mainly focuses on how low caste people became the rural elite, quite opposed to the foreseeable high castes in Kandyan peasantries. This was not just a result of a single-linear process, but a byproduct of acquiring education, once the low caste people became economically stable in the contemporary market economy. Therefore, how peasants comprehend prosperity or economic stability alongside material development is worth delineating.

"Prosperity" is identified as the ultimate goal of human life, which in turn makes people more self-reliant (Rogers, 1980). Except for a few qualities, prosperity is not universal since the prosperity highly depends upon peoples' perceived experiences, for example having a vehicle might inflate the self-efficacy in a society, on the contrary in a different context the same case might not inflates the selfefficacy. The prosperity, therefore, can be considered as a perceived fullness that is aligned with socio-cultural experiences; this is what makes the difference in the perception of rationality in different contexts.

Some argue that prosperity is the expected wellbeing and which is threefold, i.e. Physical, Social and Psychological (Maslow, 1956). Until recently, measures used in gauging prosperity were those economic indexes, and hence some 
significant social determinants of prosperity were neglected. Therefore, understanding the multidimensionality of prosperity, that look into different measurements is important since this research posits that caste like so-called irrational institutions might help reaching prosperity within rural communities.

Even though there are different types of development approaches, the entrepreneurial approach is considered to be a micro-level, self-driven mechanism which enhances peoples' capability so as to reach the expected prosperity. "Expected Prosperity" is highly contextual and specific, therefore, expected prosperity might be different from one society to another. Any small-scale or grass-root activity that drives toward expected prosperity would be an entrepreneurial task, that more often requires community participation and social capital. For some economists, the entrepreneur is one who is willing to bear the risks of a new venture if there is a significant chance for profit. Schumpeter (1994) views entrepreneurship as a force of 'creative destruction'. The entrepreneur carries out 'new combinations' thereby help rendering old endeavours obsolete. These are highly economic descriptions, but risk-bearing capacity and profit-seeking mindset are two of the significant characteristics in which the caste system involves in. Therefore, though entrepreneurial activities are highly understood as rational, the influencing social structure comprises of rational and irrational institutions can be a matter of concern to many anthropologists (Jayawardena, 2000; Roberts, 1995).

Drucker (1985), took the above idea further, describing an entrepreneur as one who actually searches for change, responds to it, and exploits change as an opportunity. The entrepreneurship seems like a new term, as if it did not exist even though community members of traditional societies sought for changes, responded to it and exploited change as an opportunity.
As a peasant society, Sri Lankan village demonstrates the importance of togetherness to the individualism, since the social structure has long been constructed by common effort or through social capital. Since the present situation is a result of historical developments, when developing rural societies in Sri Lanka, the past would be a decisive determinant (Ouellette \& Wood, 1998). Caste, a product of the historical development of the society is, therefore, likely to affect present social currents.

The socio-cultural orientation of a society influences how much entrepreneurship there is within a community. Different levels of entrepreneurship may stem from cultural differences that make entrepreneurship more or less rewarding personally (Drucker, 1985). For example, a culture that accords high status to the "selfefficacy", the individual is more likely to encourage entrepreneurship, resulting in prosperity. Notwithstanding, entrepreneurship is not a personal thing, but can be encouraged through social capital or common effort. Culture and social context, therefore are inevitable aspects of entrepreneurship which help to achieve expected prosperity, because culture represents every aspect of a social structure and organization, it might include every rational and irrational institution, that is perhaps difficult to separate, and hence it might influence how people act and make decisions in achieving expected prosperity.

The outcomes of an action may direct toward prosperity if it accords with rational principles, though the defined and perceived rationality of a particular community may be different from another. The rationality is justified more appropriately by the community in which the expected prosperity stems. Therefore, any action, which helps achieving prosperity, might be termed as entrepreneurship, a more rational process. It is, therefore, clear that so-called irrational institutions, however, may influence so- 
called rational processes since they link-up together within the social structure.

\section{Caste, Entrepreneurship and Education}

Caste is defined "as a small and named group of persons characterized by endogamy, hereditary membership and a specific style of life which sometimes includes the pursuit by tradition of a particular occupation and is usually associated with a more or less distinct ritual status in a hierarchical system"(Beteille, 2015, p. 45). Stratification, furthermore, can be described as one indispensable aspect of a society and hence at least gender stratification can be seen, though speculatively all other stratification systems can disappear. As many anthropologists posit, caste has been one of the stratification systems which originated directly from the social system (Dumont, 1972; Hutton, 1946; Nanjundayya \& Iyer, 1928). Any institution like the caste system of a society may function as long as it provides a function to the society (Fortes \& Pritchard, 1940), so that, there are several lay justifications as to why caste system is still preserved, though it does not concord with modern rationalities. To exemplify, Hinduism justifies the caste system in India, whereas for Sri Lankans it is the profession castes bring off. The integrity of several professions and the smooth functioning of the social system in the country highly depended on the caste system since it provided rules and regulations for each profession (Hussein, 2013; Silva, 2014).

The caste system in Sri Lanka is different from the Indian caste system, as the profession determines the caste rather than religious justifications. Caste divides the society into strata, but unlike in India, Sri Lankan caste stratification is a complex one, since constructing an appropriate hierarchal system is rather difficult. However, Yalman (1967) proposed a hierarchy which can be used to understand the caste system particularly in up-country rural areas in Sri Lanka. He argues that different castes cannot be positioned in a hierarchy since the dignity is relative to each other. Even though, it is possible to make a hierarchy, making out a feature of every caste based on their dignity is difficult. He, therefore, introduces a caste hierarchy comprises of four different levels. On top of the hierarchy, religious leaders are placed, since their caste identity is likely to have disappeared, however, entrants to the religious domain are strictly limited by caste norms (Yalman, 1967). Then socalled high caste or cultivators (govigama) can be placed beneath the religious leaders. Thereafter, so-called low castes relative to govigama (Cultivators) are altogether considered as service caste and placed under the govigama caste. The bottom layer of hierarchy constitutes most polluted castes such as rodi and gattara. This is a more empirical delineation of the caste system particularly in Kandyan peasantries in Sri Lanka.

Table 1: Caste hierarchy in a Kandyan village

$\frac{\text { Buddhist Monks }}{\text { Govigama Caste }}$
Service Castes: Berava, Wahumpura, Nawandanna, Hunu, Pedi, Hannali, Rada
$\frac{\text { Most Polluted Castes: Rodi and Gattara }}{1}$

Source : (Yalman, 1967) 
Identifying a particular group of people relatively high or low is highly controversial since it is difficult to pinpoint qualifiers in labelling a person or a group. However, peoples' life-world experiences can be used as general guidelines in order to make out the societal placement ( high or low) of a particular group in the society (Husserl, 1965; Luckman, 1978). Philosophically it would be difficult to justify the placement of castes, though the placement has always been justified by laypersons. Yalman (1967) appropriates the ethnomethodology in order to understand up-country caste system in Sri Lanka, and it was explained that exact placement of middle level or service castes can be difficult to identify since their position might be variant according to the persons' perceptions and experiences (Pieris, 1956). However, the position of the high caste people (govigama) and mostly polluted castes (rodi and gattara) have never changed. The best way, therefore, is to prepare a caste hierarchy in relation to govigama and most polluted castes.

Caste, some anthropologists argued as a set of rules and regulations for the integrity of professions (Leach, 1960, 1961; Srinivas, 1962, 2003), whereas some argue that caste comprises of a moral order which governs every aspect of people's behaviour (Dumont, 1972). Marxist anthropologists would prefer to look at caste as a stratification system which discriminates people (Redfield, 1956; Wolf, 1966).

As far as studies on the caste system in Sri Lanka is concerned, some significant studies have been conducted in line with a cultural-anthropological perspective. However, most of them are highly conscious of the importance of the caste system. They also strived to understand its relevance in the contemporary Kandyan peasantries. Some of the studies, furthermore, have been conducted to reveal changes in the caste and its impact on human behaviour. Even today, some researchers (Paramsothy, 2018; Silva,
1999) have critically described issues around caste system and its new faces, which influence societies tremendously.

Early classical anthropological accounts such as "Under the Bo Tree", "Pul Eliya", "Land Tenure in Village Ceylon", "Caste in Modern Ceylon", more often discussed the nature of the caste system alongside its importance, and further asserted the significance of that caste system in the social order. Nonetheless, changes of castes and its relationship with modern and rational structures were studied by Roberts (1995) based on low-country caste system and elitism, a phenomenal study. Roberts argues that the Karave Caste of lowcountry Sri Lanka climbed-up over other high castes due to wealth accumulation under the colonial administration (Roberts, 1995). This argument further exemplified by Jayawardena (2000) specifying that nobodies including low castes had later become somebodies owing to the wealth they accumulated through various colonial enterprises. Jayawardena (2000), furthermore studied how caste identity influenced gaining prestige and which in turn uplifts the status of low castes, which helps them exploit chances of the society including political positions and higher positions in branded enterprises.

Changing identities of castes significantly influenced the political power as to whom should be given the responsibility and authority to exert it. Politics is all about acquiring power and making decisions. Politics plays an important role in every corner of an organized society. Though the acquiring power and making decisions are interrelated, sometimes they can be separated but consequently, anarchy may be stemmed (Castells, 2010). Elitism, a concept which introduces a group of people who have the decision making power provided that they are comprised of economic, social and political prestige, can be identified in situations where acquiring power and decision making are separated (Fierlbeck, 1991; Mills, 1956). 
As the British invasion changes the society in many ways, it also caused the political stability of the country alongside the economic prosperity, since the invasion severely challenged the existing caste system by introducing arbitrary noncontextualized policies such as the abandonment of Royal Tributary System (Rajakari Kramaya). [Note: Rājakāriya was a political system in ancient Ceylon that was based on feudalism in which the king and other aristocratic people were given prominence. Offering a royal tributary, a responsibility of all people, carried out the feudal system in ancient Sri Lanka. This was solely performed by the caste system. The land, a scarce resource in the Kandyan Kingdom was distributed among different castes as a permeant wage, so that people were bound to the apportion of their labour and profit from lands, and supposed to tribute to the King, in the sense political system of the country was functioned on the basis of tributary system]. This influenced the low country caste system and low-castes had given the chance to rise since their profession was quite aligned with entrepreneurial principles that could not be seen in other castes. Karave( Fishermen), Durave (Distillers) and Salagama (Cinnamon Producers) had been really aligned with the expectation of foreign rulers such as Dutch and British (Bieddermann \& Strathern, 2017). Therefore, those caste groups escalated their status mostly through economic gains or wealth accumulation. Later, they struggled for political power and were able to achieve it, and hence they could act as elite, however, they could exert the achieved power only after accompanying high caste families through marriages, and they gained prestige through it, which otherwise could not (Jayawardena, 2000).

At the inception of the class formation based on specific castes, education did not play a major role, but later it did in order to acquire the prestige, even in low country peasantries (Roberts, 1995). Education is a powerful tool to acquire achieved status, which stimulates the self-efficacy of the people. Education is the act or process of imparting or acquiring general knowledge, developing the power of reasoning and judgment, and generally of preparing oneself or others intellectually for mutual life (Gelpi, Shimahara, \& Ipfling, 2017; Harber, 2014; UNESCO, 2016). Even though education is considered a highly rational process, it links up with irrational institutions, since it functions on a society where rational and irrational institutions are interrelated.

Typical caste system had been preserved for a long period in Kandyan peasantries unlike that of the low-country, as invasions of British rulers were not succeeded until 1815 (Pieris, 1956). However once the Kandyan kingdom was captured by British rulers, many changes took place in Kandyan highland peasantries. Even though in the name of rationality, several government interventions took place in terms of rural development, the people have experienced various unexpected obstacles (Henegedara, 2012; Scudder, 2005; Uphoff, 1992). In spite of those obstacles, rational interventions somehow encouraged some peasants, particularly the low caste people to enrich life chances utilizing their professional capabilities in the market economy. This was furthered due to vernacular school education prevailed in Kandyan highlands, after 1960's public policy reforms of the country (Robinson, 2007).

Kandyan highlands of the country had remained untouched by foreign invaders for many decades, unlike many low country peasantries in the country; therefore, people of the low country experienced several changes within the colonial period when compared to Kandyan people. Due to administrative and economic policies introduced by the British government, the low country peasantries became modernized, and hence elite formation in line with traditional caste identities bespoke. On the contrary, in Kandyan peasantries, though some government interventions took place after 1815 AD, 
people in remote areas were reluctant to stand with those British policies. Consequently, several insurgencies have emerged in early and mid ninetieth century of the Kandyan kingdom. Those uprisings were not just movements against the British administration but were a representation of troublesome transitions in the social structure in rural areas of the country. Since reflections toward the British administration in up-country Sri Lanka were quite nontolerant, the transformation of its structure had some differences that of the low country caste system in Sri Lanka. Importantly, elite formation and rural development appeared to be different from the low-country situation in Sri Lanka.

However, class formation promoted by caste identities, particularly in Kandyan peasantries has not been studied thoroughly through a cultural anthropological perspective except for a few studies conducted to understand caste and its functions within the social organization. This research, therefore, endeavoured to help understand how class formation (promoted by caste identities) came off as a by-product of rural development processes that include educational interventions, which is in fact, a mechanism of intensifying modern values in rural areas.

\section{Problem and Objective of the Study}

Peasantries in Kandyan highlands have undergone numerous changes over the past few decades due to various reasons, though interventions by the government in terms of development brought up some benefits. After 1978, it was obvious that different policy reforms impacted on the rural social structure, particularly in Kandyan highlands, as most of the development projects directed toward and more focused on up-country peasantries (Scudder, 2005). For about several decades, since Kandyan peasantries in Sri Lanka had preserved its inherent and historically developed social structure and constricted foreign invasions, even after decolonization, that traditional social structure affected rural development interventions in many different ways. During this period how Kandyan peasantries have involved in the marketoriented development process, and in particular why the low caste people in Kandyan highland peasantries benefitted from education, once they have secured their economic gains whereas the high caste people could not do is quite an intriguing problem that is worth investigating, therefore.

The objective of the study, therefore, is to understand how low caste people in a Kandyan village adapted their mindset to acquire economic benefits in the market economy.

\section{METHODOLOGY}

Meanings of social action emanate from everyday life-world reasoning, but not beyond it (Garfinkle, 1967). The responsibility of a researcher is, therefore, to find out that lay perspective on social actions, by capturing a complete picture. Therefore, conventional knowledge in which laypersons understandings are involved, shall be revealed in order to understand the reality. Meanings of people's action in a structured society are legitimized by themselves, but not by theoretical explanations produced (Garfinkle, 1967). Therefore, ethnomethodology was employed as the methodology in this research. Since the objective of this research was to identify how Kandyan caste system has been restructured, once the forces of globalization came into rural societies, therefore, how laypersons have perceived their social situation must be revealed. The most suitable methodology, therefore, would be the ethnomethodology.

Though Kandyan highlands have undergone several changes during the past few decades, there are some peasantries still preserved. So that, following the guidelines provided by ethnomethodology a field study was carried out in five traditional villages in Walapane divisional 
secretariat (a remote rural area located in Nuwara Eliya District). Rasingolla, Dambagolla, Karndagolla and Kotambe are four adjacent villages of this area; therefore, the researcher stayed at a village house for about two weeks (December, 2017) and collected data. Then, Teripaha, a remote village of the area have been studied (One week, January, 2018). Interviews and direct observation methods were employed in the data collection phase. The collected data thus were analyzed thematically.

\section{FINDINGS AND DISCUSSION}

The social organization of rural Sri Lanka has undergone several changes while preserving some traditional institutions during the transitional period after neoliberal reforms introduced. Once neoliberal reforms were introduced, though several changes took place in Kandyan peasantries, some traditional institutions have not been diminished as they significantly influenced the social structure. As people's identity and experiences came from their relationship with those traditional structures, people were strongly reluctant to accede with unconventional practices. This was why some conventional social structures influenced unconventional or novel interventions in the rural society. Furthermore, since neoliberal policies were imposed on the feudal social structure in Sri Lanka, later development interventions too brought some benefits, though that bespoke some inequalities, because inequalities in traditional rural society were again affected the rural development process. Findings furthermore reveal that neoliberal interventions in the contemporary Kandyan peasantries have altered the conventional or traditional social structure largely.

\section{Identity, Mobilization and Education}

Due to its traditional and authoritative identity, high caste communities could not mobilize upwardly like that of the low castes. Inherently high caste groups had a socially accepted and justified dignity and identity. Therefore, seemingly rural development interventions considerably have not reached these people, in the sense, high caste people were not involved in those development-related activities as those were considered more universal, which disqualified conventional structures like ascribed status, that feared those high caste people, as they would dispossess their traditional authoritative identity. High caste people, therefore, did not involve those rational interventions, because they were just satisfied with the inherited prosperity aliened to dignity and identity from generation to generation. This is quite a hidden case to the knowledge already existing.

Many development interventions have catered to high caste people since they are in a more advantageous position, though it has not been the case in the studied area. Non-Governmental Organizations were seriously conscious about matters regarding the low caste communities and provided necessary facilities to enrich their wellbeing. This appears to be a positive discrimination of achieving justice; however, those so-called high caste communities were not only discriminated but were ideologically readjusted not to seek mobility, since they ideally believed that they were the highest. Therefore, the mobility of the Kandyan high caste communities has been lessening when compared to the low caste communities of Kandyan highlands.

Particularly many women in high caste groups (Govigama: Nilamakkara and Govi) could not attend schools, because the mode of thought constructed in line with the caste identity did not allow it.

I can remember that schooling was restricted to me. My mother also did not have any positive idea toward schooling. They thought that it was appropriate to her status (since she was a kumari hamy [a high caste woman]), and we were able-bodied in the sense we could possible survive without having education, at that time. Unlike 
today, we did not think education to be a necessary thing. Many girls in my family did not enter schools. This was quite similar to many govigama Families in our village. (Woman, 56)

This makes sense that intersections are highly influential on how people behave in the society. Caste is not just a discrete stratification system, and it intersects with other societal stratification systems. Caste intersects the gender stratification, in the sense caste is gendered. Gender is socially constructed in which identities and roles of male and female are specified, and hence the caste influences men and women differently. This is quite evident in Kandyan rural areas too. The high caste women were considered more prestigious and have not exposed to the public since it was highly believed that women might cause caste contamination. The structural arrangement of the rural society favoured men in the purity of caste, as contamination might happen probably due to misconduct of women, who would bear a child by a caste-exogamic parson (a person outside the caste).

As conceived by Kandyan peasants, caste can be contaminated if a low caste man impregnates a high caste woman. In the past, high caste men were allowed to have low caste women as concubines, but the first woman to marry must be from a high caste. Low caste men can have concubines, but they were not allowed to marry high caste women by the norm. Quite opposed to what Yalman (1964) observed, now polyandry is not practised in these peasantries, though some caste norms related to marriages still persist. Marriagerelated caste norms perhaps hinder women's progress in peasantries in the modern day. When compared to the low caste women, the high caste women, therefore, held back from the public sphere particularly because of the marriage-related caste norms. Consequently, women from high caste groups were held back from education institutions in rural areas; this resulted in dissatisfaction in latter stages of their lives.
Nandawati [person's name] together with some other wahumpura (a low caste) girls came to the school in this village, so my father suggested me to go to the school in the near city, because he did not like to see me playing and get along with low caste people (Adu kule Minissu). As suggested, just I went to the City high school, but it was quite difficult, as I had to travel every day for a long distance. Therefore, after SSC Examination (now Ordinary Level or Grade 11 examination) I refrain from attending the school. Now I regret that improvident decision, when I look at Nandawati teaches at this village school. At that time, I did not realize the importance of the education, nor my parents; but we had much money. Now I am just a housewife who cooks and does household chores. However, Nandawati like low caste women went up. (Woman, 53)

The high caste people were not conscious on outcomes of the education, as they already possessed a substantial social status and they were the elite. Therefore, they did not want to lose their identity by getting on with the low caste people. So that, women of the high caste communities have not exposed to the public sphere thereby deviating them from a formal education to a considerable extent, and which resulted in poverty, later. On the contrary, many low caste girls have enjoyed quite a greater level of freedom in gaining a good education that of the high caste girls, consequently, they acquired a selfsatisfaction.

All my family members made jaggery and sweets. In the mid 50's government established a school in our village. So I went there, and I wanted to be a teacher. Now I am a teacher in the same school. Fortunately, the school was established very close to my home. When it was established some govigama girls came, but 
eventually they did not. It was because they did not want to intermingle with us. But we girls from whumpura (jaggery making) caste remained learning. (Woman, 52)

Except for few cases, women in the high caste families kept out of the public sphere. The high caste women just wanted to go along with traditional caste principles and they remained at home, and consequently, their upward mobility was hindered. The less mobility has resulted in the less advancement among high caste women. Women and even men were kept far from the modern education system, at the outset of rural development interventions due to identity conflict among different caste groups. The parents of high the caste families were seriously conscious of their aristocratic identity, and they did not like to renounce it, as though other benefits too denounce at the same time. In addition, they continued to go with what they had been doing for several generations, and children were expected to do the same thing.

Some teachers from different areas were not very enthusiastic to teach us. Since many of them were from high castes, they were reluctant to teach us. It was only after three times I passed the SSC Examination. Nevertheless, I somehow entered the Peradeniya University later and became a teacher. It was quite a hard time. (Man, 46)

The inherited specific identity, on the other hand, encouraged the low caste people to go along with the market economy, thereby mobilizing their potentials to play an active role. Moreover, those low caste people strived to enrich their lives through economic gains acquired utilizing their professional potentials, so that they got along with modern rationalities, children from those communities too entered schools, as parents were so keen on the identity that can be achieved through education, in spite of having a high pressure from the high caste people. Aristocratic pressure and its impact on the low caste people in relation to education was clearly captured by Ryan (Ryan, 1953). The specificity of the identity, one that oppresses the low caste people encouraged to search for a new identity, that was supported by the market economy and education, that of the high caste people.

Many high caste men too have not attended schools as inherent aristocratic identity and societal prestige hindered them from mixing with other caste people. They did not want to mingle with low caste members in schools since that would have harmed their aristocratic identity and the highly prestigious mindset. I just wanted to go to a school. Exactly
I went, but I myself found that it was
difficult to intermingle with many low
caste boys. Then I stopped schooling...
Later I went to school in an urban area,
however, that was also not very
comfortable since transportation
facilities were very bad at that time. In
the end, I had to stop schooling and I
opted to take care of the family
property. (Man, 42). 
Picture 1: A Deteriorated Govigama house, Teripaha

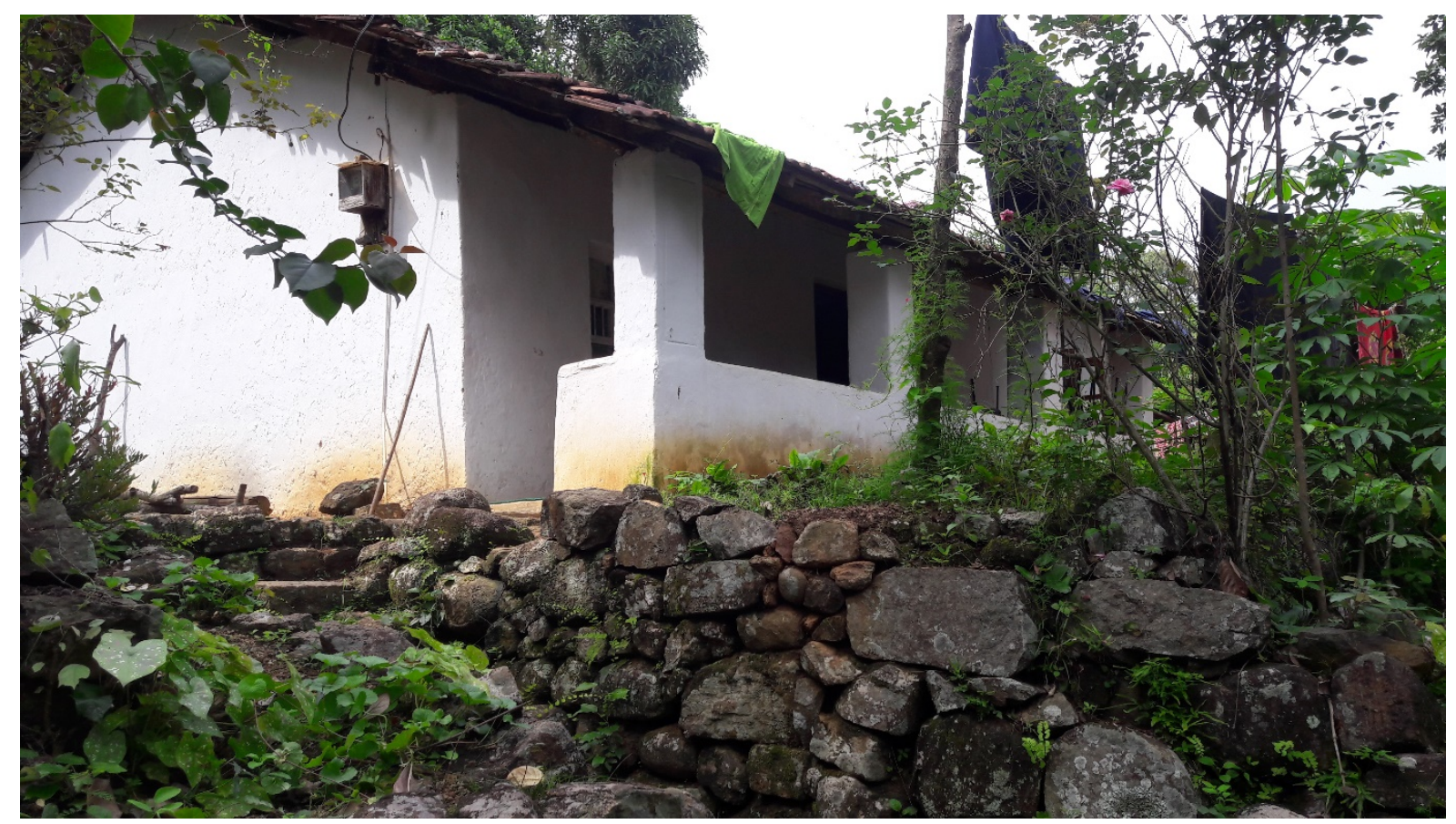

Source: Author, Captured: $31^{\text {st }}$ December, 2017

Alongside preserving their caste identities, men have to go along with professional activities, as an inherent responsibility, since they are considered to be active members of the patrilineal descent system. Men, therefore, bear traditional professional responsibilities, and this would be more opportune to low caste men that of the high caste men, since high caste men are not specialized in any profession in the traditional societal sphere except for agriculture and tobacco production. This indirectly helped the low caste men to mobilize themselves in line with rational interventions like rural development and education. For example, jaggery makers (wahumpura caste) who can make sweets and jaggery started small businesses such as "Sweet Stalls" that would bring money.

This makes it clearer that being a member of a low caste encouraged them to look for a new identity that does not oppress them longer. This was a collective ideology, and hence the low caste people more often searched for new opportunities in the modern market economy. They utilized their inherent professional abilities, furthermore formal government education supported them, by and large, despite aristocratic oppression persisted to a considerable extent.

\section{Caste, ideological change and elitism}

Two significant features that fudge together the caste system in Kandyan peasantries are the inherited profession and the professional identity, which presents in the public and private spheres. Bonded or the inherited profession demonstrates the material aspect of the caste, whereas identity shows the ideological/subjective aspect. Ideological aspect is rather important as it governs the behaviour of the people in such a way that the community members are solidified. Identity might be represented in the society with "high" or "low-level" dignity relatively. The high caste groups are likely to have high dignity, on the contrary, low dignity with the low castes. The level of dignity can be identified as highly influential in rational interventions to rural development. As high caste communities are comprised of a greater level of dignity, they just strived to 
preserve their existing status complying with existing norms and it did not require any arbitrary effort by peasants as the norms were already there in the society.

\begin{abstract}
At that time, washermen came home to wash our clothes, despite having the ability to wash our clothes, our father instructed us not to do it and give those clothes to washer-men. Moreover, they were just paid. Father might have thought that it could be the responsibility of washer-men to wash high caste people's clothes. (Woman, 40)
\end{abstract}

The above excerpt demonstrates how a norm was prevailed and complied by the society. This can be interpreted using structural functionalism (Fortes \& Pritchard, 1940), though our endeavour is to identify to what extent the caste influenced entrepreneurship of the people which then enhanced by the government education, giving rise to rural elite those who were influential in making decisions in rural societies, later on. Low caste communities sought for a high dignity by any mean, but at first, it was difficult to challenge the ideology since it had been constructed over a long societal history. Therefore, it seems that they directed their consciousness toward material gains at first, as it would obviously align with modern-rational principles in the formation of class identities, in the market-oriented society.

I am from the washer-man ( $r a d a)$ caste. Now I am running a Beauty Salon. I earned a diploma from an institute. My father told me that he did not have a sufficient knowledge except for washing clothes, so he started a laundry. Through that he earned money. Then he came to the city of this area and set-up a house. However, I do not like to run a laundry. Therefore, I earned a diploma and now running a beauty salon, it is a profitable enterprise. Anyway, my father still runs the laundry. (Man, 32)
The income was, furthermore, a matter of caste identity in the past, now, however, it has been changed. Now class identity formation would be a result of economic gains. Low caste groups did not have a prestigious identity, therefore they struggled to become prestigious and benefitted group through education and being entrepreneurs based on their caste related capabilities. For example, Berava people (tom-tom beaters) used their ability to make income through providing wedding ceremony banquet services. Caste-based occupations became prominent in the market due to its specificity and necessity, therefore service castes could engage in market-oriented income generating activities.

The reflections of peasant-life is another significant determinant, which determines the structure of peasant social organization. What people perceive being a member of the society, particularly in a caste group affects how they behave in that society. Though it seemed the low caste people identified themselves as inferior to high castes, they have not interrogated it since they were just adjusted to the social structure and lived with it. So that unconsciously, low castes were more often suppressed, but they did not perceive their situation as bad. In addition, no opportunity was available for them to come out of the stamped identity since social structure inherently favoured the high caste people. However, when the market economy entered the rural society, the suppressed low castes began to compare themselves with those who enjoy equal rights. This was where the peasant's status quo ideology transformed. 


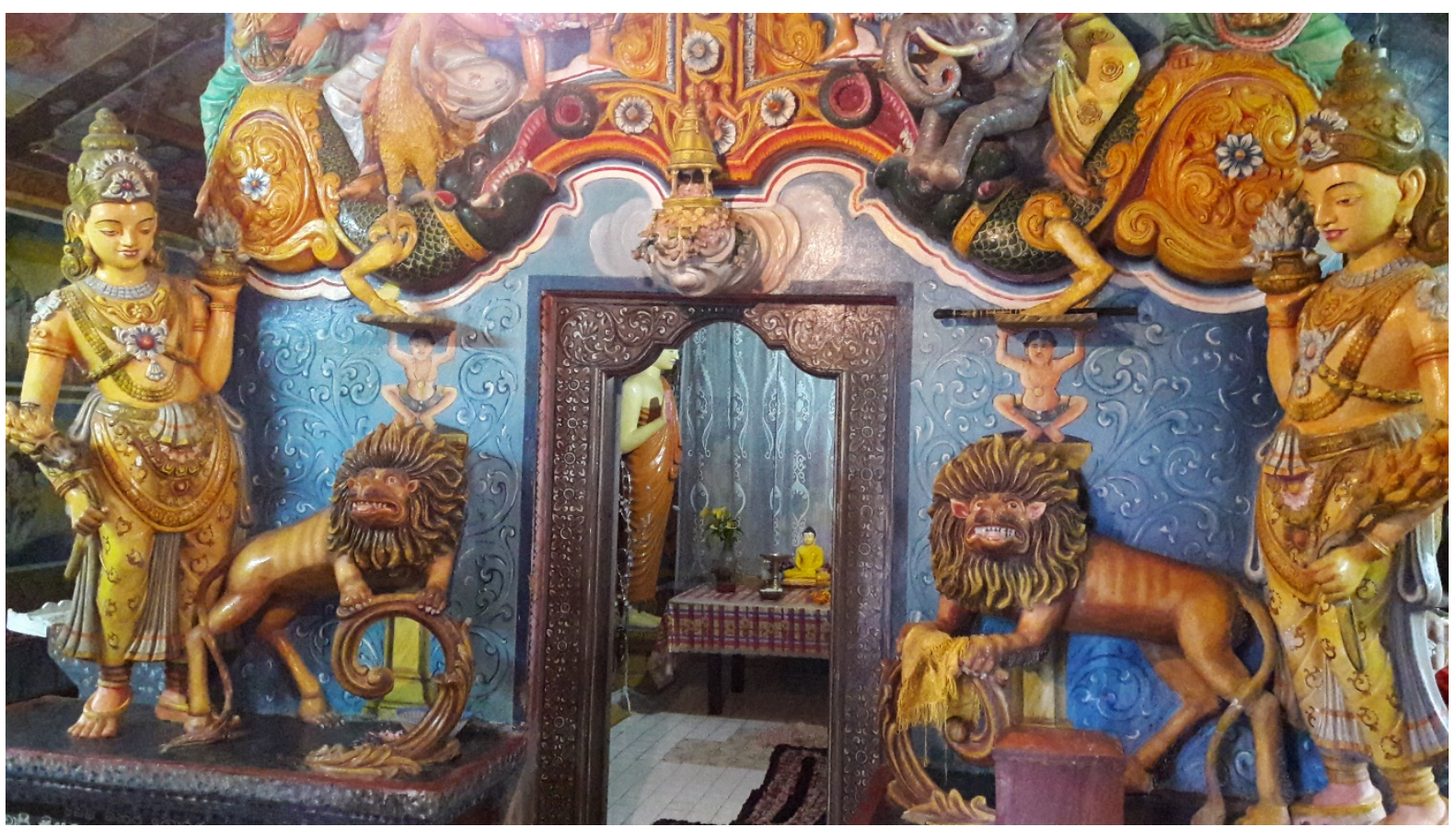

Source: Author, Captured: $31^{\text {st }}$ December 2017

The ideological transformation stimulated them to think beyond existing structural boundaries so that low castes started to mobilize their existing professional capacities aligned with the market economy.

\section{These people know everything though that does not need. Mobile phone and the TV seriously transformed this village. Unlike in the past, they now try to do new things. It is ok, but there are several unexpected disadvantages too. Some berava people now offer banquet packages. I do not know how this new generation learns these things. Many low caste people in this village are more job focused. (a Buddhist monk, 60)}

The low castes entered the market economy in many different ways since they had necessary professional capacities, consequently, the monetary capital was congregated around the low castes. Therefore, they became the new hegemonic class in peasantries, since they possessed a substantial amount of monetary capital that affects the social structure of peasantries. The low caste people invested the money and they also spend it on religious and cultural events to gain a social acceptance. Moreover, the high caste people understood that it might be difficult to persist without the low caste peoples' cooperation in transforming peasantries, though low caste identity kept as it was. The low caste people, therefore, strived to uplift their social identity in many different ways, such as acquiring education and sponsoring religious and cultural events in the village. (See picture 2)

Bearava people are now an essential group of this village. Earlier they respected us unconditionally. Now we have to respect them, why? without their contribution, we cannot organize even an annual procession of the temple. Dambagolla, a tom-tom beaters' village is now so full-fledged than our area. Earlier, we had walawwas [marvellous aristocratic house], but now they have been 
deteriorated, while low castes built-up modern houses. The main reason was we did not try since our high caste identity hindered it. (Man, 66)

The aristocratic mindset hindered mobilization of high caste peasants. Rasingolla, Theripaha, Dmabagolla like peasantries were started by aristocrats from the central Kandyan kingdom, therefore aristocrats did not have any specific professional ability that suits the modern market economy. The peasant feudal system persevered due to norms introduced by those aristocrats, however, once global values prevail over traditional rural societies, aristocrats could not further their aristocracy. The mismatch between that aristocratic ideology and prevailing global values hindered mobilization of the high castes while strengthening the low castes' upward mobility.

\section{Adopting modern norms and transformation of the identity}

As the economic globalization prevails, norms and values appropriated in the market economy swallowed the rural society. Peasants, therefore, adopted those norms in their lives, so that particularly anything marketable became more prominent. During this period of transition, professions performed by low castes became market-oriented. This facilitated them to appropriate their labour in the market. Though the caste related identity have not been changed, what they have done were reinterpreted during this transformation, consequently, the low caste people struggled to earn money by utilizing their inherent capacities.

For example, wedding banquet package service (Berava, Badde), laundries (Rada), sweet makers (Wahumpura), hotel owners (wahumpura) popped out in rural areas. Once low caste people have earned a sufficient amount of wealth through appropriating their inherent capabilities in the market economy, the inferior mindset has been weakened gradually. So that, afterwards the low caste people struggled to search for a social prestige, during which education was chosen as the best possible mechanism. Furthermore, those low caste people were more often engaged in community service activities, in search of a socially justified prestige in their villages. Therefore, newly constructed buildings in religious places were most of the time sponsored by those low caste people (Picture 2: Teripaha).

\section{Entrepreneurship, caste and elitism}

Except for a few high caste persons, many low caste people became entrepreneurs since they demonstrated a high level of specialization in some professions, creativity, dedication to the work, determination and the self-confidence comes from the bonding social capital. [Note: Bonding social capital is a type of social capital that describes connections within a group or community characterized by high levels of similarity in demographic characteristics, attitudes, and available information and resources. Bonding social capital exists between 'people like us' who are 'in it together' and who typically have strong close relationships. Examples include family members, close friends, and neighbours]. The table 1 shows how Tom-tom beaters' caste (Berava) demonstrates entrepreneurial qualities. 
Table 2: Qualities and Characteristics of tom-tom beaters, which make them entrepreneurs

\begin{tabular}{|c|c|}
\hline Quality & Characteristic \\
\hline Existing Knowledge & Producing drums, Dancing, Performing rituals, Astrology \\
\hline Creativity & $\begin{array}{l}\text { Make use of the existing knowledge to satisfy } \\
\text { contemporary capitalist needs (banquet services) }\end{array}$ \\
\hline Dedication & $\begin{array}{l}\text { Dedicate time and other resources to acquire more skills } \\
\text { and perform their duty in a well-organized way }\end{array}$ \\
\hline Determination & $\begin{array}{l}\text { Coming out from the low caste identity at first, then to be } \\
\text { successful in the modern society }\end{array}$ \\
\hline Bonding-social capital & Strong links among community members \\
\hline
\end{tabular}

Source: Author

The entrepreneurial qualities of many low caste people helped utilize existing capabilities in the market economy. Afterwards, during their walk toward gaining high social prestige, education provided a substantial support. Education reinforced the rise of the low caste people as an elite group, which in turn encouraged them to further their capital seeking endeavour. Unlike earlier times, after many decades, school education tremendously supported the second and third generation's low caste people in getting benefits from the market economy. Furthermore, identity transformation too sustained due to school education.

\section{Out-migration and emergence of rich- caste pockets}

Out-migration of resourceful persons from low caste groups due to inner rural unrest, in turn, contributed to the sophistication of caste groups. [Note: Rural Unrest Inherently there was a conflict among different castes in Kandyan peasantries, though different ground level mechanisms hindered it. Harmony of rural societies was maintained by the religion. Functional integrity of different castes too contributed to the harmony of Kandyan peasantries. However, once transformation started, low castes claimed their equal rights in the society. On the other hand, high caste people stressed their high caste identity and reluctant to access with a market-driven society. Therefore, ironically it emerged as a conflict between high and low castes, though it was not apparent.] Education has provided necessary means for the sustenance of low caste households thereby making those people more resourceful in knowledge and skills. On the contrary, a conducive environment was not there to make use of those skills, so that they were motivated to migrate to urban areas from the current living place. Out-migration also intensified, because of the school education. However, temporarily migrated persons, in turn, sent remunerations from urban areas to the village; this caused sophistication of caste pockets. Caste pocket can be identified as a specific area in the community, which is more developed when compared to other parts of the village.

I passed the advanced level examination and completed a computer diploma too. However, it was quite difficult to use my knowledge and skills in the village since I was labelled as low caste. Therefore, I migrated to Colombo and got married to a girl, but regularly visit my hometown as well. (Man, 35)

When the transformation of rural social structure intensified, suppressed and low identity of service castes had declined gradually, adopting a new identity in line with values obtained from modern and rational education. 


\section{Becoming elite in rural areas}

The elite determines how society should run since they possess the political power over other inhabitants in the society. The elite constitutes a group of people, who share the same identity alongside common norms and values, and they are distinguished from the commons particularly in rural areas. The aristocrats or the high caste govigama were the elite in the past, as they owned the political power in the village. Two distinct aspects determine the rural politics, such as the greater level of economic stability of the group and the high level of identity granted by the society. The aristocratic govigama people have had those qualities in the past as they claimed, however, once modernization appropriated the rural society they were relinquished. Having authority over the village by high caste people has now become a legacy.

Three generations back, one of my ancestors purchased this land from the British government and constructed a village. At that time, they ruled this village, because they were the landowners. The land was distributed among different castes so that they were required to provide a service in return. Now things have been changed. My Mutta [the earliest ancestor] constructed the temple of this village, but now no one knows that. (Man, 70)

The aristocrats were forced to give up their control over the village, as the low caste people owned economic growth through their enterprises. As described earlier, during past few decades, service castes have become wealthier, in the sense they were able to secure their economic stability that might influence the rural society in different ways. Furthermore, service or low castes could acquire a relatively high level of social identity through school education, so that they could legitimize their importance of the presence in the society. Therefore, the ownership of the political power has been gradually shifted from the high caste govigama aristocrats to the low caste people. Teachers, Schoolmasters, Agricultural instructors, Sellers and moneylenders took the control over the village, despite some resistance have been strategically dealt with.

Table 3: Elite identity formation of low castes and gaining prosperity in a Kandyan Village

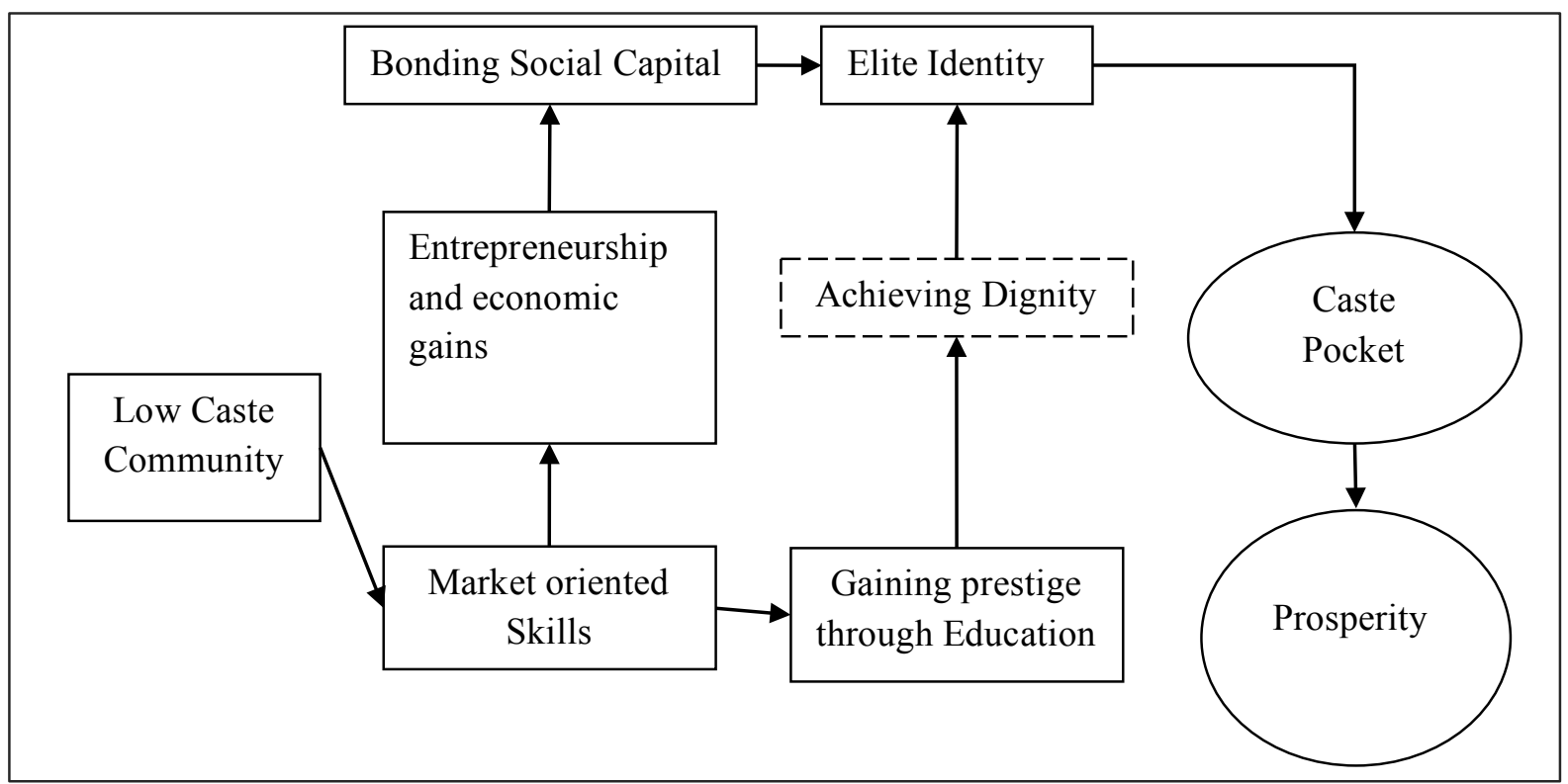

Source: Author 
The significant role of high castes has been steadily declining, though their high level of traditional identity remained unchanged. However, the traditional identity of the high castes has no stake in the transitional rural societies, as the low castes or the service providing castes take over the control of peasantries. This makes it clear that the low castes (service castes) benefitted that of the high castes once the forces of globalization came into the rural society.

How those low caste communities achieved their prosperity and in which ways education like rational institutions contributed to it, is conceptualized in the Table 3. (This will be summarized in the conclusion).

\section{CONCLUSION}

The globalization has prevailed even in remote rural societies, particularly getting them adjusted in the market economy. Therefore, during the past few years, peasantries in Kandyan highlands have undergone significant changes, this included transforming the rural social structure that appropriates the market economy. Many cultural anthropologists have studied changes and their impact on human behaviour tremendously, particularly in Kandyan highland peasantries. They understood that, though a

Low castes were specialized in professions more valued in the market economy. Relatively the low level of identity of those service-providing castes was tolerated in the past, as they were not conscious on and did not reflect their true status in the hieratical social structure, even though later this began to change. When the market economy came in, service castes were able to make use of their professional capabilities in order to earn money, this resulted even in ideological change. Moreover, the low castes also seemed to have some entrepreneurial qualities that encouraged them to be more active during considerable transformation had been taken place, some significant social structures were not changed, as they were decisive drivers in the social organization. The paper perceived this paradox in line with the argument of prevailing rationalities over irrational domains, particularly in contemporary Kandyan peasantries The forces of globalization vastly affected the rural social structure in Sri Lanka, so that modernization began even in rural societies with different faces. As a result, so-called modern rational values were instilled in Kandyan peasantries, even though beliefs regarding traditional caste system were not completely disappeared. Some of the development interventions (including government education), therefore had to go along with those traditional social structures, which resulted in unexpected consequences, such as conflicts among different castes, out-migration, deterioration of ethics and the kind. Mainly, low castes (service providing castes) have benefitted from this transformation, while high caste people have not. Low castes, except for rodi, have benefited during the transitional period, mainly because they have had more appropriate and marketoriented professional capabilities. This was later supported by the school education. In addition, there were several other factors contributed to the upward mobility of the low castes in this area.

the gradual transformation of those peasantries. When service castes accede with the structural transformation of the village, they furthermore perceived themselves different from other high caste govigama people, during which internal bonds (bonding social capital) strengthened, that resulted in a struggle to acquire economic power and high level of social identity over other high caste people. The economic gains together with elevated social identity directed the society toward a low caste elitism, through which the low castes exert their micro-level political power on the village. 


\section{ACKNOWLEDGEMENTS}

For his substantive comments on the earlier draft of this work, I am grateful to M.G. Manuratne, $\mathrm{PhD}$, a senior lecturer in Sociology at University of Peradeniya, Sri Lanka. I also wish to acknowledge Mr. Seneviratne, Mrs. Nilanka, Mrs. Punyawathi, Mr. T.B. Seneviratne, those who supported me with collecting data on which this work relies.

\section{REFERENCES}

Bandarage, A. (2007). The Separatist Conflict in Sri Lanka. NY: iUniverse, Inc.

Beteille, A. (2015). Caste, Class and Power: Changing Patterns of Stratification in a Tanjore Village (3 ed.). Oxford: University Press.

Biedermann, Z., \& Strathern, A. (Eds.). (2017). Sri Lanka at the Crossroads of History. University College London: UCL Press.

Castells, M. (2010). End of Millennium. Cambridge (MA): Blackwell Publishers.

Chambers, R. (1983). Rural Development: Putting the Last First. New York: Longman.

Chambers, R. (1997). Whose reality counts? London: ITGD Publishers.

Chung, H. (2013). Rural transformation and the persistence of rurality in China. Eurasian Geography and Economics, 54(5-6), 594-610. doi:10.1080/15387216.2014.902751

Cruickshank, J., Lysgård, H. K., \& Magnussen, M. 1. (2009). The logic of the construction of rural politics: political discourses on rurality in Norway. Geografiska Annaler: Series B, Human Geography, 91(1), 73-89. doi:10.1111/j.1468-0467.2009.00307.x

Desai, V., \& Potter, R. B. (2011). The Companion to Development. London: Hodder Education.
Douwe van der Ploeg, J. (2010). The pleasantries of the twenty-first century: the commoditisation debate revisited. The Journal of Peasant Studies, 37(1), 1-30. doi:10.1080/03066150903498721

Drucker, P. (1985). Innovation and Entrepreneurship. London: Harper Collins.

Dumont, L. (1972). Homo Hierarchicus: The Caste System and its Implications (6 ed.). London: Paladin.

Eckes, A., \& Zeiler, T. (2003).

Globalization and the American

Century. New York: Cambridge University Press.

Ember, C. R., \& Ember, M. (2015). Cultural Anthropology. Boston: Pearson.

Fierlbeck, K. (1991). Vilfredo Pareto, The Rise and Fall of Elites: An Application of Theoretical Sociology. Canadian Journal of Sociology, 17(3), 120-121.

Fortes, M., \& Pritchard, E. E. E. (1940). African Political Systems. New York: Oxford University Press.

Frank, A. G. (1993). The World System. London: Routledge.

Frederick, N. (1991). Industrialization and development. Journal of International Development, 3(1), 79-85. doi: 10.1002/jid.4010030107

Garfinkle, H. (1967). Studies in Ethnomethodology. New Jersey: Prentice-Hall, INC.

Gelpi, E., Shimahara, N., \& Ipfling, H.-J. (2017). Education Encyclopcedia Britannica. London: Encyclopædia Britannica, inc.

Giddens, A. (2003). Runaway World: How Globalization is Reshaping our Lives. New York: Routledge.

Harber, C. (2014). Education and International Development: Theory, Practice and Issues. Oxford: Symposium Books.

Held, D. (2004). Global Covenant: The Social Democratic Alternatives to the Washington Consensus. Cambridge: Polity Press. 
Held, D., McGrew, A., Glodblatt, D., \& Perraton, J. (1999). Global Transformation: Politics, Economic and Culture. Cambridge: Polity Press.

Henegedara, M. (2012). Globalization And Rural Development.

Hussein, A. (2013). Caste in Sri Lanka: From Ancient Times to the Present Day. Colombo: Neptune Publications.

Husserl, E. (1965). Phenomenology and the Crisis of Philosophy. Kegan Paul: Trubner and Co, Ltd.

Hutton, J. H. (1946). Caste in India: its Nature, Function and Origin. Cambridge: Cambridge University Press.

Jayawardena, K. (2000). Nobodies to Somebodies: The rise of the colonial bourgeoisie in Sri Lanka. Colombo: Social Scientists Association.

Leach, E. R. (1960). Aspects of Caste in South India, Ceylon and North West Pakistan. Cambridge: University Press.

Leach, E. R. (1961). Pul Eliya: A Village in Ceylon. Cambridge: Cambridge University Press.

Luckman, T. (1978). Phenomenology and Sociology. England: Penguin Books.

Manogaran, C. (1974). Traditional Versus Modern Agriculture: A Study of Peasant Farming in Ceylon (Sri Lanka). Geografiska Annaler: Series B, Human Geography, 56(2), 68-77. doi:10.1080/04353684.1974.11879390

Maslow, A. (1956). Self-actualizing People: A study of Psychological Health. New York: Harper \& Row.

McLeod, J. (2010). Begining Post Colonialism (1 ed.). New Delhi: Viva Books.

Mills, C. W. (1956). The Power Elite. New York: Harcourt.

Moran, D. (2000). Introduction to Phenomenology. London: Routledge.

Nanjundayya, H. V., \& Iyer, L. K. A. (1928). The Mysore Tribes and Castes (Vol. 2). Mysore: The Mysore University.

Ouellette, J. A., \& Wood, W. (1998). Habit and Intention in Everyday Life: The Multiple Processes by Which Past
Behavior Predicts Future Behavior Psychological Bulletin, 124(1), 54-74.

Paramsothy, T. (2018). Caste within the

Sri Lankan Tamil Diaspora: Ūr

Associations and Territorial

Belonging. 2018, 18(1).

Patel, S. (2017). Colonial Modernity and Methodological Nationalism: The Structuring of Sociological Traditions of India. Sociological Bulletin, 66(2), 125-144.

Pieris, R. (1956). Sinhalese Social Organisation. Colombo: University of Ceylon Press.

Raghavan, M. D. (1957). Handsome beggars: the Rodiyass of Ceylon. Colombo: Colombo Book Centre.

Redfield, R. (1956). Peasant Society and Culture: an Anthropological Approach to Civilization. University of Chicago Press: Chicago.

Rescher, N. (2003). Epistemology: An Introduction to Theory of Knowledge (G. R. Lucas Ed.). New York: State University.

Roberts, M. (1995). Caste Conflict and Elite Formation. New Delhi: Navarang.

Robinson, M. S. (2007). Political Structure in a Changing Sinhalese Village. Cambridge: Cambridge University Press.

Rogers, C. R. (1980). A way of being. Boston: Houghton Mifflin.

Ryan, B. (1953). Caste in Modern Ceylon: The Sinhalese System in Transition (Vol. New Jersey): Rutgers U.P.

Schumpeter, J. A. (1994). Capitalism, Socialism and Democracy. New York: Routledge.

Schutz, A. (1977). Phenomenology and the Social Sciences. In F. R. Dallmayr \& T. A. McCarthy (Eds.), Understanding and Social Inquiry. Notredam and London: University of Notredam Press.

Scudder, T. (1997). Social Impact of Large Dam Projects. World Bank initiative on Large Dams, 1(1), 41-68.

Scudder, T. (2005). The Future of Large Dams: Dealing with Social, 
Environmental, Institutional and Political Costs. London: Earthscan.

Shah, E. (2012). 'A life wasted making dust': affective histories of dearth, death, debt and farmers' suicides in India. The Journal of Peasant Studies, 39(5), 1159-1179. doi:10.1080/03066150.2011.653344

Shiva, V. (1991). Ecology and the Politics of Survival: Conflicts over Natural Resources in India. New Delhi: Sage.

Silva, K. T. (1999). Caste, Ethnicity and Problems of National Identity in Sri Lanka. Sociological Bulletin, 48(1/2), 201-215.

Silva, K. T. (2014). Caste, Class and Conflicts in Sri Lanka [Kulaya, Panthiya ha Sri Lankawe gatum]. Colombo: Vidarshana Publishers.

Spencer, J. (1990). A Sinhala Village in a Time of Trouble: Politics and Change in Rural Sri Lanka. Delhi: Oxford University Press.

Srinivas, M. N. (1962). Caste in Modern India and Other Essays. Bombay: Asia Publ. House.

Srinivas, M. N. (2003). Religion and Society among the Coorgs in India. New York: Oxford University Press. Stiglitz, J. (2002). Globalization and its Discontents. New York: WW Norton \& Company.

Tepicht, J. (1975). A project for research on the peasant revolution of our time.
The Journal of Peasant Studies, 2(3), 257-269.

doi:10.1080/03066157508437935

UNDP. (2017). Human Development Report 2016: Human Development for Everyone. New York: United Nations Development Programme.

UNESCO. (2016). Education for People and Planet: Creating Sustainable Future for All Retrieved from Place de Fontenoy:

Uphoff, N. (1992). Learning From Galoya: Possibilities for Participatory Development and Post-Newtonian Social Science. London: Cornell University Press.

Weber, M. (1947). The Theory of Social and Economic Organization (A. M. H. T. Parsons, Trans. 1st American Edition ed.). New York: Oxford University Press.

Wolf, E. R. (1966). Peasants. New Jersey: Englewood Cliffs.

Yalman, N. (1964). The Structure of Sinhalese Healing Rituals. In E. B. Harper (Ed.), Religion in South Asia. Seattle: University of Washington.

Yalman, N. (1967). Under the Bo Tree: Studies in Caste, Kinship and Marriage in the interior of Ceylon. Los Angeles: University of California Press. 